\title{
PENERAPAN DATA MINING ALGORITMA K-MEANS CLUSTERING PADA POPULASI AYAM PETELUR DI INDONESIA
}

\author{
1) Elsa Ramadanti, ${ }^{2)}$ Muhamad Muslih \\ ${ }^{1,2)}$ Program Studi Sistem Informasi, Fakultas Teknologi Informasi dan Komputer, Universitas Nusa Putra \\ ${ }^{1,2)}$ Jl. Raya Cibatu Cisaat No.21, Cibolang Kaler, Kec.Cisaat, Kab.Sukabumi - Jawa Barat - Indonesia \\ E-mail : elsa.ramadanti_si18@nusaputra.ac.id,muhamad.muslih@nusaputra.ac.id
}

\begin{abstract}
ABSTRAK
Telur ayam merupakan jenis telur yag mudah dijumpai dan digemari banyak orang. Sehingga kebutuhan masyarakat akan telur ayam sangat diperlukan untuk memenuhi kebutuhan sumber protein hewani dan nutrisi hariannya. Penelitian ini menganalisis Penerapan Data Mining Algoritma K-Means Clustering pada Populasi Ayam Petelur di Indonesia. Sumber data populasi ayam ras petelur di Indonesia di peroleh dan dikumpulkan melalui situs web Badan Pusat Statistik Nasional. Data yang digunakan terhitung dari tahun 2016-2020 yang terdiri dari 34 provinsi. Data akan dikelompokkan ke dalam 3 cluster yaitu cluster populasi tinggi, sedang, dan rendah. Pengolahan data dilakukan secara manual di Microsoft Excel dan dibantu tools data mining yaitu Rapidminer dan Orange. Hasil dari pengolahan data tersebut menunjukkan hasil yang sama yaitu 1 provinsi untuk cluster populasi tinggi, 3 provinsi untuk cluster populasi sedang dan 30 provinsi untuk cluster populasi rendah. Tujuan penelitian ini adalah agar pemerintah dan peternak lebih memperhatikan jumlah populasi ayam petelur di Indonesia berdasarkan cluster yang telah dilakukan untuk menjaga keseimbangan jumlah dan kestabilan harga telur di masyarakat.
\end{abstract}

Kata Kunci : Data Mining, K-Means, Clustering, Populasi, Ayam Ras Petelur

\section{ABSTRACT}

Chicken eggs are a type of egg that is easy to find and favored by many people. So that the community's need for chicken eggs is needed to meet the needs of animal protein sources and their daily nutrition. This study analyzes the application of the K-Means Clustering Algorithm Data Mining on the Layering Poultry Population in Indonesia. The source of data on the population of laying hens in Indonesia is obtained and collected through the website of the National Statistics Agency. The data used is from 2016-2020 which consists of 34 provinces. The data will be grouped into 3 clusters, namely high, medium, and low population clusters. Data processing is done manually in Microsoft Excel and assisted by data mining tools, namely Rapidminer and Orange. The results of the data processing show the same results, namely 1 province for the high population cluster, 3 provinces for the medium population cluster and 30 provinces for the low population cluster. The purpose of this study is for the government and breeders to pay more attention to the number of laying hens in Indonesia based on clusters that have been carried out to maintain a balance in the number and stability of egg prices in the community.

Keyword: Data Mining, K-Means, Clustering, Population, Laying Chicken

\section{PENDAHULUAN}

Meningkatnya pertumbuhan populasi penduduk disertai dengan masyarakat yang sadar akan pola hidup seimbang sehingga tingkat konsumsi masyarakat terus meningkat di berbagai sektor, terutama di sektor peternakan pada kelompok ayam petelur. Besarnya pertumbuhan penduduk dibandingkan dengan laju pertumbuhan pasokan produk peternakan menyebabkan konsumsi telur ayam meningkat tajam. Saat ini populasi ayam petelur meningkat setiap tahunnya karena tingginya permintaan telur ayam, kebutuhan tersebut belum terpenuhi, sehingga pelaku ekonomi di bidang ayam petelur perlu meningkatkan produksinya untuk memenuhi kebutuhan pasar[1].

Permintaan telur ayam tergantung pada kebutuhan masyarakat Indonesia akan protein hewani. Dihitung berdasarkan konsumsi per kapita, daya beli tergantung pada struktur pendapatan masyarakat, faktor sosial budaya, dan letak geografis di Indonesia. Dari sisi permintaan telur meningkatkan permintaan telur ayam berdasarkan jumlah kebutuhan perkapita di masyarakat, maka harga telur pun semakin tinggi. Seperti daya beli masyarakat ataupun struktur pendapatan sangat menentukan permintaan konsumen akan telur ayam. Jika struktur pendapatan masyarakat tinggi, maka konsumsi telur ayam relatif tinggi, 
begitu pula sebaliknya[2].

Mengenai permasalahan di atas, peneliti akan menerapkan data mining melalui metode $\mathrm{k}$ means clustering untuk menganalisis populasi ayam petelur di setiap provinsi di Indonesia. Data mining adalah ekstraksi pola yang menarik dari besarnya jumlah data. Strategi dikatakan menarik jika tidak sepele, implisit, asing, dan bermanfaat. Strategi yang disajikan harus mudah di mengerti, dapat digunakan dalam data yang bisa diperkirakan dengan tahap ketetapan tertentu, baru dan bermanfaat[3]. Sedangkan K-Means Clustering merupakan metode analisis non-hierarchical clustering, yang berusaha membagi objek atau data menjadi beberapa cluster yang telah ditentukan sesuai dengan karakteristik masing-masing cluster[4]. Proses clustering dibagi menjadi 3 cluster untuk mencari provinsi dengan populasi ayam petelur tertinggi, sedang dan terendah. Penelitian ini ditujukan untuk menerapkan algoritma k-means clustering pada data populasi ayam petelur di setiap provinsi Indonesia.

\section{Tinjauan Pustaka}

Ada beberapa penelitian terkait yang digunakan sebagai tinjauan pustaka untuk mendukung dalam proses penelitian ini yakni sebagai berikut:

a. Florida Ivonia Manek, Sutan Faisal, Bayu Priyatna menyatakan dengan menerapkan metode K-Means Clustering dapat digunakan untuk pengelompokkan pelanggan dengan menghasilkan tiga cluster. Hasil Clustering tersebut terdiri dari 12 pelanggan dari cluster rendah, 6 pelanggan dari cluster sedang dan 4 pelanggan dari cluster tinggi. Penelitian ini berhasil menerapkan K-Means Clustering dalam menentukan pelanggan mana yang lebih diprioritaskan sesuai dengan data penjualan tersebut oleh perusahaan ayam itu sendiri[5].

b. Viya Miralda, Muhammad Zarlis, Eka Irawan dalam penelitiannya menjelaskan penerapan metode K-Means Clustering bisa digunakan untuk mengelompokkan daging ayam buras sebagaimana mestinya. Data untuk penelitiannya diperoleh dari www.bps.go.id[6] yaitu data penduduk miskin (2012-2018) dari 34 provinsi di Indonesia. Dari penelitian ini menyatakan 2 cluster diantaranya cluster tinggi berjumlah 8 provinsi dan cluster rendah berjumlah 26 provinsi dengan menggunakan salah satu tools data mining yaitu RapidMiner. Hasil dari penelitian bisa menjadi saran agar pemerintah dapat memberikan perhatian lebih untuk melaksanakan penyuluhan dan penyerahan bantuan pada masyarkarat di setiap provinsi Indonesia berdasarkan cluster yang telah dilakukan[7].

c. Pada penelitian Suhardi Rustam dalam menerapkan metode K-Means dengan optimasi jumlah kluster ini diperoleh dari data mahasiswa yang sudah mengambil mata kuliah konsentrasi angkatan 20162017. Proses pengelompokkan kelas mata kuliah konsentrasi mahasiswa semeter akhir ini dengan menggunakan tools data mining yaitu Orange menghasilkan 5 kluster dengan masing-masing nilai di setiap klusternya berbeda secara berurutan dari kluster 1 sampai kluster 5 sebagai nilai terbaik dari kluster lainnya. Maka dalam penelitian ini membuktikan metode $\mathrm{K}$ Means dengan bantuan tools data mining yaitu aplikasi Orange dapat diterapkan dan berhasil dalam pengolahan data akademik mahasiswa[8].

\section{METODE}

Pada penelitian ini peneliti bertujuan untuk mengelompokkan data populasi ayam petelur dari tahun 2016 - 2020 terdiri dari 34 provinsi di Indonesia dengan algoritma K-Means Clustering. Ada beberapa tahapan untuk melakukan proses metode K-Means Clustering yaitu sebagai berikut:

\section{Studi Literatur}

Pada tahap ini peneliti mencari landasan teori dan bahan-bahan yang didapatkan dari beberapa sumber yaitu jurnal ilmiah dan bahan referensi yang berhubungan dengan judul dan metode yang digunakan dalam penelitian untuk 
melengkapi penelitian sehingga memiliki bahan referensi yang baik dan relevan.

\section{Pengumpulan Data}

Data penelitian ini berasal dari data yang dikumpulkan melalui website https://www.bps.go.id[6], diantaranya adalah data sekunder yaitu data populasi ayam petelur di 34 provinsi Indonesia dari tahun 2016-2020.

\section{Pengolahan Data}

Pengolahan data ini dilakukan untuk mendapatkan hasil dari pengelompokan data yang ada, dimana data tersebut nantinya akan menjadi 3 cluster, yang meliputi provinsi dengan populasi ayam petelur tertinggi, sedang, dan terendah.

\section{Evaluasi dan Analisis Hasil}

Pada tahap ini peneliti menemukan dan menganalisis hasil dari perhitungan k-means clustering baik itu hasil dari perhitungan secara manual maupun dengan menggunakan 2 alat bantu (tools) data mining yaitu dengan RapidMiner dan Orange. Kemudian hasil yang didapat bisa dijadikan masukan bagi peternak dan pemerintah untuk memberikan perhatian lebih pada populasi ayam petelur di berbagai provinsi Indonesia.

\section{HASIL}

\section{Data Populasi Ayam Petelur di Indonesia}

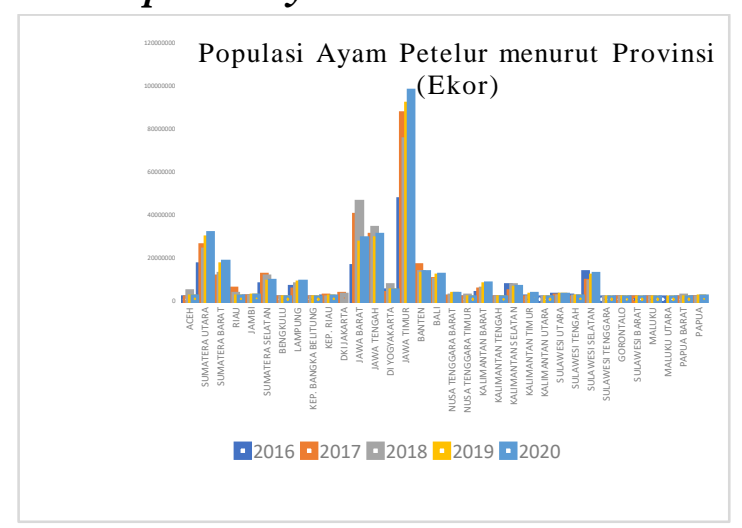

Gambar 1. Populasi Ayam Petelur
Dari data yang sudah ada pada diagram tersebut, langkah awal yang harus dikerjakan adalah mengerjakan perhitungan manual $\mathrm{K}$ Means Clustering terlebih dahulu. Adapun langkah-langkah proses algoritma K-Means Clustering di antaranya yaitu::

a. Menentukan jumlah cluster untuk digunakan dalam pengelompokkan pada data yang telah tersedia. Cluster yang dibuat ada 3 cluster yaitu cluster populasi tinggi, sedang dan rendah.

b. Menentukan titik pusat cluster centroid awal (iterasi 1) yang ditentukan secara acak. Titik pusat cluster yang telah ditentukan terlihat pada tabel dibawah ini:

Tabel 1. Titik Pusat Awal Cluster

\begin{tabular}{ccc}
\hline Centroid 1 & Centroid 2 & Centroid 3 \\
\hline 45880658 & 23838 & 1266673 \\
\hline 86000243 & 0 & 303345 \\
\hline 73773529 & 0 & 674304 \\
\hline 90639492 & 4908 & 768134 \\
\hline 96543331 & 5228 & 818167 \\
\hline
\end{tabular}

c. Menghitung jarak antara data dari titik pusat cluster ke centroid terdekat. Centroid terdekat tersebut dijadikan pusat cluster untuk perhitungan selanjutnya. Adapun rumus persamaannya sebagai berikut :

$$
d(P, Q)=\sqrt{\sum_{j=1}^{p}\left(x_{j}(P)-x_{j}(Q)\right)^{2}}
$$

Keterangan :

$\mathrm{D}=$ jarak

$\mathrm{P}=$ data record

$\mathrm{Q}=$ data centroid 
Tabel 2. Hasil Perhitungan Jarak Terdekat Cluster Iterasi 1

\begin{tabular}{|c|c|c|c|c|c|}
\hline No. & $\mathrm{C} 1$ & $\mathrm{C} 2$ & C3 & $\begin{array}{c}\text { Jarak } \\
\text { Terdekat } \\
\end{array}$ & Cluster \\
\hline 1 & 178002043 & 2661045,4 & 3367410,08 & 2661045,418 & $\begin{array}{c}\text { Cluster } \\
2 \\
\end{array}$ \\
\hline 2 & 124719789 & 53990895 & 55577079,2 & 53990894,88 & $\begin{array}{c}\text { Cluster } \\
2\end{array}$ \\
\hline 3 & 151775944 & 27190780 & 28798568,4 & 27190780,17 & $\begin{array}{c}\text { Cluster } \\
2 \\
\end{array}$ \\
\hline 4 & 176522250 & 4552905,3 & 5031795,56 & 4552905,348 & $\begin{array}{c}\text { Cluster } \\
2 \\
\end{array}$ \\
\hline 5 & 177827545 & 1159369,9 & 2392175,59 & 1159369,904 & $\begin{array}{c}\text { Cluster } \\
2 \\
\end{array}$ \\
\hline .. & ..... & ..... & ..... & $\ldots .$. & ..... \\
\hline 34 & 179473667 & 1283780,9 & 891941,055 & 891941,0548 & $\begin{array}{c}\text { Cluster } \\
3\end{array}$ \\
\hline
\end{tabular}

Tabel 3. Hasil Cluster Iterasi 1

\begin{tabular}{ccc}
\hline Cluster & Provinsi & Hasil \\
\hline C1 & 15 & 1 \\
\hline & $1,2,3,4,5,6,8,10,11,12,13,1$ \\
C2 & $4,16,17,18,19,20,22,23,25$, & 24 \\
& $26,27,33,34$ & \\
\hline C3 & $7,9,21,24,28,29,30,31,32$ & 9 \\
\hline
\end{tabular}

\section{Populasi Ayam Petelur}

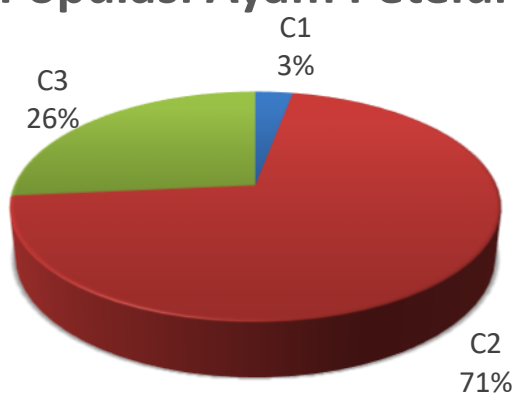

$\square \mathrm{C} 1 \square \mathrm{C} 2 \square \mathrm{C} 3$

Gambar 2. Clustering Data Iterasi 1

d. Kemudian menghitung ulang centroid ke titik pusat cluster selanjutnya dengan ratarata kelompok data yang ada pada cluster tersebut dengan rumus berikut:

$$
C=\frac{\Sigma \mathrm{m}}{\mathrm{n}}
$$

Dimana:

C : centroid data

$\mathrm{m}$ : anggota data yang dimiliki oleh centroid tertentu

$\mathrm{n}$ : jumlah data yang merupakan anggota centroid tertentu e. Proses K-Means akan terus berulang (iterasi) hingga pengelompokan data sama dengan pengelompokan data dari iterasi sebelumnya. Sampai proses iterasi terhenti pada iterasi ke 8 untuk hasil akhirnya terlihat pada tabel berikut.

\section{Tabel 4. Hasil Cluster Iterasi 8}

\begin{tabular}{ccc}
\hline Cluster & Provinsi & Hasil \\
\hline C1 & 15 & 1 \\
\hline C2 & $2,12,13$ & 3 \\
\hline C3 & $1,3,4,5,6,7,8,9,10,11,14,16$, & 30 \\
& $17,18,19,20,21,22,23,24,25$, & \\
& $26,27,28,29,30,31,32,33,34$ & \\
\hline
\end{tabular}

\section{Populasi Ayam Petelur}

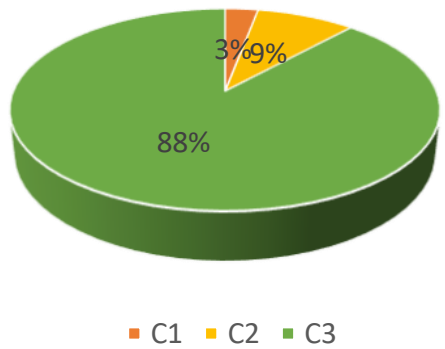

Gambar 3. Clustering Data Iterasi 8

Dalam iterasi ke 8, nilai dari titik centroid untuk setiap cluster tidak mengalami perubahan dan perpindahan data dari tiap clusternya.

\section{Hasil Implementasi Tools Data Mining}

Berikut akan ditampilkan hasil implementasi dari tools data mining yaitu RapidMiner dan Orange, di antaranya terlihat pada tampilan gambar sebagai berikut:

\section{Hasil Implementasi Tools RapidMiner}

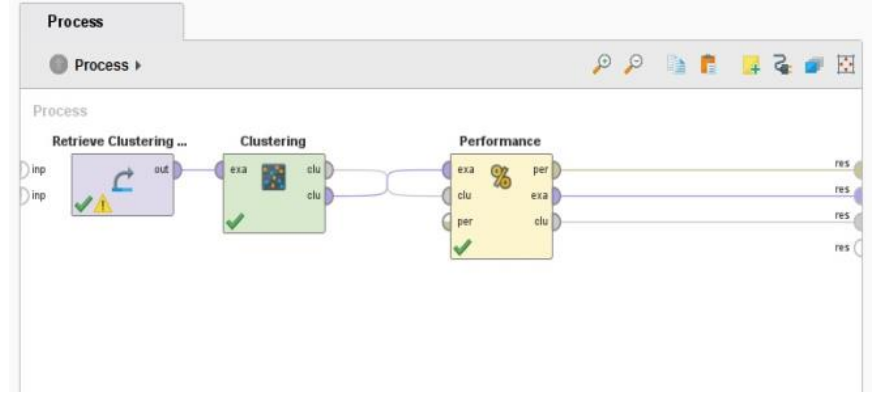

Gambar 4. Proses Clustering pada RapidMiner 


\section{Cluster Model}

Cluster 0: 30 items

Cluster 1: 1 items

Cluster 2: 3 items

Total number of items: 34

Gambar 5. Hasil Clustering RapidMiner

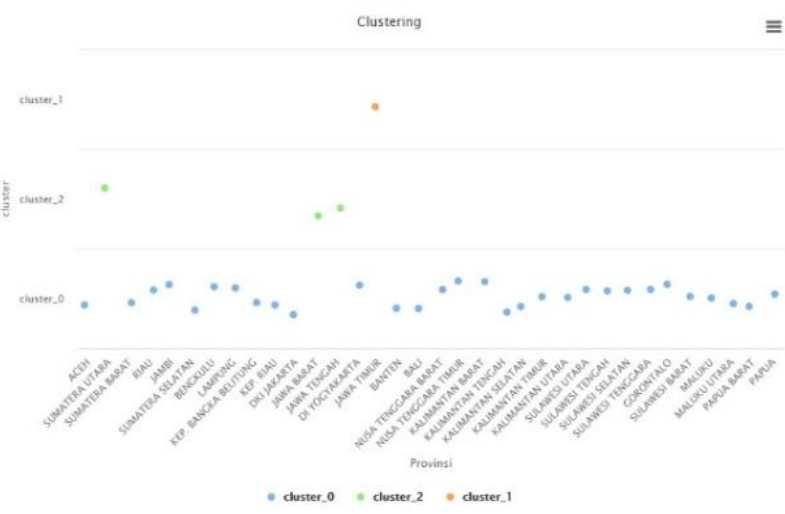

Gambar 6. Hasil Akhir Pengelompokan Rapidminer

\section{Hasil Implementasi Tools Orange}

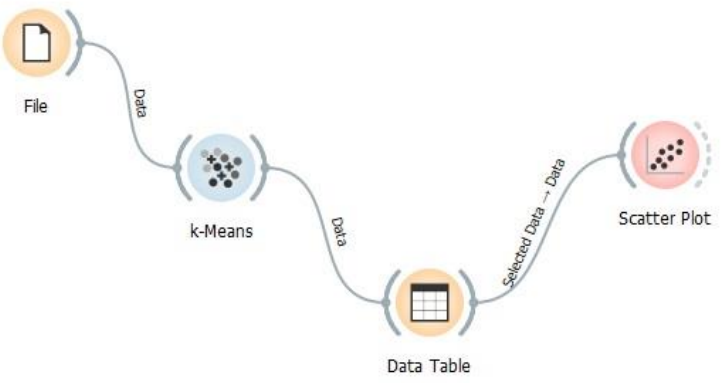

Gambar 7. Proses Clustering pada Orange

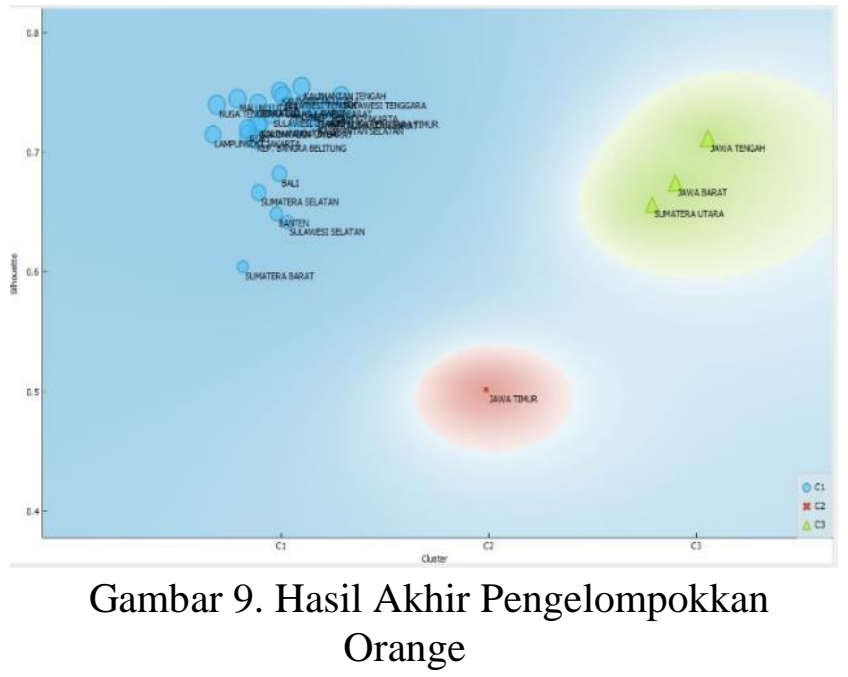

Perbandingan Hasil (Output) dari 3 Jenis Proses Perhitungan K-Means Clustering

Setelah dilakukan perhitungan K-Means Clustering baik secara manual maupun dengan 2 tools data mining tersebut, maka dapat dilihat beberapa perbandingan dari ketiga hasil output yang di dapat, yaitu sebagai berikut: 
Tabel 5. Perbandingan Hasil

\begin{tabular}{cccc}
\hline \multirow{2}{*}{ Keterangan } & \multicolumn{3}{c}{ Proses } \\
\cline { 2 - 4 } & Manual & Rapidminer & Orange \\
\hline Jumlah Iterasi & 8 & - & 8 \\
\hline \multicolumn{4}{c}{ Jumlah Data } \\
\hline Cluster 1 & 1 & 1 & 30 \\
\hline Cluster 2 & 3 & 3 & 1 \\
\hline Cluster 3 & 30 & 30 & 3 \\
\hline $\begin{array}{c}\text { Populasi } \\
\text { Tertinggi }\end{array}$ & Cluster 1 & Cluster 1 & Cluster 2 \\
\hline $\begin{array}{c}\text { Populasi } \\
\text { Sedang }\end{array}$ & Cluster 2 & Cluster 2 & Cluster 3 \\
\hline $\begin{array}{c}\text { Populasi } \\
\text { Terendah }\end{array}$ & Cluster 3 & Cluster 3 & Cluster 1 \\
\hline
\end{tabular}

\section{KESIMPULAN}

Berdasarkan hasil pengelompokkan populasi ayam petelur di berbagai provinsi Indonesia dengan mengimplementasikan tools Data Mining yaitu RapidMiner dan Orange dengan algoritma K-Means Clustering, maka kesimpulan yang dihasilkan sebagai berikut :

a. Penerapan algoritma K-Means Clustering untuk pengolahan data populasi ayam petelur di Indonesia dari ketiga jenis perhitungan secara manual dan dengan implementasi tools Rapidminer dan Orange menghasilkan sebuah hasil (output) yang sama.

b. Dari hasil (output) yang telah diperoleh dari proses penerapan metode k-means clustering, maka hasil dari ketiga perhitungan diatas yaitu 1 provinsi untuk cluster populasi tinggi yaitu Jawa Timur. Untuk cluster populasi sedang ada 3 provinsi di antaranya Sumatera Utara, Jawa Barat dan Jawa Tengah. Sedangkan untuk cluster populasi rendah ada 30 provinsi di antaranya Aceh, Sumatera Barat, Riau, Jambi, Sumatera Selatan, Bengkulu, Lampung, Kep.Bangka Belitung, Kep.Riau, DKI Jakarta, DI Yogyakarta, Banten, Bali, NTB, NTT, Kalimantan Barat, Kalimantan Tengah, Kalimantan Selatan, Kalimantan Timur, Kalimantan Utara, Sulawesi Utara, Sulawesi Tengah, Sulawesi Selatan, Sulawesi Tenggara, Gorontalo, Sulawesi Barat, Maluku,
Maluku Utara, Papua Barat, Papua.

c. Hasil dari proses menerapkan data mining denganmenggunakan algoritma k-means clustering pada populasi ayam ras petelur ini dapat dijadikan sebagai saran dan masukan bagi pelaku ekonomi dibidang pemerintah untuk memberikan perhatian lebih pada setiap provinsi berdasarkan cluster untuk menjaga keseimbangan jumlah populasi dengan permintaan dan kestabilan harga telur di setiap provinsi di Indonesia.

\section{DAFTAR PUSTAKA}

[1] Aldi, "Kelayakan Finansial Usaha Peternakan Ayam Ras Petelur," Pap. Knowl. . Towar. a Media Hist. Doc., pp. 12-26, 2018.

[2] A. A. Hamzah, "Profil Komoditas Telur Ayam Ras," 2020. .

[3] M. Marsono, D. Saripurna, and M. Zunaidi, "Analisis Data Mining Pada Strategi Penjualan Produk PT Aquasolve Sanaria Dengan Menggunakan Metode K-Means Clustering," J-SISKO TECH (Jurnal Teknol. Sist. Inf. dan Sist. Komput. TGD), vol. 4, no. 1, p. 127, 2021, doi: 10.53513/jsk.v4i1.60.

[4] M. G. Sadewo, A. P. Windarto, and D. Hartama, "Penerapan Datamining Pada Populasi Daging Ayam Ras Pedaging Di Indonesia Berdasarkan Provinsi Menggunakan K-Means Clustering," InfoTekJar (Jurnal Nas. Inform. dan Teknol. Jaringan), vol. 2, no. 1, pp. 6067, 2017, doi: 10.30743/infotekjar.v2i1.164.

[5] F. I. Manek, S. Faisal, and B. Priyatna, "Penerapan K-Means Clustering untuk Mengelompokkan Pelanggan Berdasarkan Data Penjualan Ayam," Techno Xplore J. Ilmu Komput. dan Teknol. Inf., vol. 3, no. 2, pp. 88-93, 2018 , doi: 10.36805/technoxplore.v3i2.820.

[6] Badan Pusat Statistik, "Badan Pusat Statistik," 2017. https://www.bps.go.id/linkTableDinami s/view/id/960. 
[7] V. Miralda, M. Zarlis, and E. Irawan, "Penerapan Metode K-Means Clustering Untuk Daging Ayam Buras," Build. Informatics, Technol. Sci., vol. 2, no. 2, pp. 91-98, 2020, doi: 10.47065/bits.v2i2.493.

[8] S. Rustam, "Penerapan Optimasi Jumlah Kluster Pada Kmeans Untuk Pengelompokan Kelas Mata Kuliah Kosentrasi Mahasiswa Semester Akhir," Simtek J. Sist. Inf. dan Tek. Komput., vol. 5, no. 1, pp. 1-5, 2020, doi: 10.51876/simtek.v5i1.64. 